Jurnal Kimia Sains dan Aplikasi 22 (1) (2019):1-6
ISSN: 1410-8917
Jurnal Kimia
Aplikasi
e-ISSN: 2597-9914

\title{
Theoretical Study of the Use of Cyano Acid Derivatives as Electron Acceptors in Cyanidin as Compounds of Dye Sensitized Solar Cells (DSSC)
}

\author{
M. Nur Maulidin Mahmud ${ }^{\mathrm{a},{ }^{*},}$, Sudarlin ${ }^{\mathrm{a}}$ \\ ${ }^{a}$ Chemistry, Faculty of Science and Technology. UIN Sunan Kalijaga Yogyakarta, Indonesia \\ * Corresponding author:13630021@student.uin-suka.ac.id
}

https://doi.org/10.14710/jksa.22.1.1-6

\section{Article Info}

Article history:

Received: 4 August 2018 Revised: 26 November 2018 Accepted: 7 December 2018 Online: 31 January 2019

Keywords:

DSSC; HOMO-LUMO; Coupling constant (VRP);

Light harvesting efficiency; and Bond length of sensitizer with $\mathrm{TiO}_{2}$; Cyanidine

\section{Abstract}

Theoretical study of the use of cyano acid derivatives as electron acceptor groups in cyanidine as dye compounds of dye sensitized solar cells (DSSC) has been carried out based on energy parameters of HOMO-LUMO, LUMO electron localization, spectra, light absorption efficiency, coupling constants, and sensitizer bond length with $\mathrm{TiO}_{2}$. This study aims to determine the effect of cyanoacetic acid, cyanoacrylic benzothiadizole, cyanovinyl acid and cyanosynamic acid as electron acceptors on the photoelectric characteristics of cyanidine and determine the cyanoic acid derivative which can produce cyanidine photoelectric characteristics better based on energy parameters HOMO-LUMO, LUMO electron localization, spectra, light harvesting efficiency, coupling constant (VRP), and bond length of sensitizer with $\mathrm{TiO}_{2}$. This research begun with molecular optimization using DFT and TDDFT method with basis set of $6.311 \mathrm{G} *$. HOMO-LUMO parameters used the same method with analysis technique using ECCE. The LUMO electron localization parameters use the same method, but the analysis technique used ECCE. Spectra using DFT method, using analytical technique using Chemcraft. Parameters of light absorption efficiency using DFT and TDDFT method with calculation technique using existing equations. Coupling constant parameters using the same method, the calculation technique used the energy equation of dye compounds were calculated in the conditions of HOMO, LUMO and $\mathrm{TiO}_{2}$ energy. Parameter length of the sensitizer bond with $\mathrm{TiO}_{2}$ were calculated used DFT method with avogadro analysis technique. Cyanidin cyanoacetate became the best modification based on HOMO LUMO energy parameter -4.569 and $-1.01 \mathrm{eV}$, respesctively. In the electron localization parameter, the best modification was produced in cyanidine cyanoacetate with an electron-centered pattern on the cyanoacetic group. Spectra parameters produced the best modification, cyanoacetic cyanidine with a wavelength of $378.811 \mathrm{~nm}$ with osillator strength of 0.633 . The light absorption efficiency parameters resulted in the best modification of cyanidin cyanoacetate with a value of 0.767 . For parameter of clutch constant, best modification is cyanidin benzothiadizol sianoakrilik with a value -0.269 . The best modification on the parameter length of the sensitizer bond with $\mathrm{TiO}_{2}$ was cyanidine cyanoacetate with a bond length of $1.926 \AA$. 


\section{Abstrak}

Kata Kunci:

DSSC; HOMO-LUMO;

Konstanta Kopling;

Lokalisasi LUMO; Panjang

Ikatan; dan Sianidin
Kajian teoritis penggunaan turunan asam siano sebagai gugus akseptor elektron pada sianidin sebagai senyawa dye sel surya tersensitasi (DSSC) telah dilakukan berdasarkan parameter energi HOMO-LUMO, lokalisasi elektron LUMO, spektra, efisiensi penyerapan cahaya, konstanta kopling, dan panjang ikatan sensitizer dengan $\mathrm{TiO}_{2}$. Penelitian ini bertujuan untuk mengetahui pengaruh asam sianoasetat, benzothiadizol sianoakrilik, asam sianovinil, dan asam sianosinamik sebagai akseptor elektron terhadap karakteristik fotoelektrik sianidin dan menentukan turunan asam siano yang dapat menghasilkan karakteristik fotoelektrik sianidin lebih baik berdasarkan parameter energi HOMO-LUMO, lokalisasi elektron LUMO, spektra, efisiensi penyerapan cahaya (light harvesting efficiency), konstanta kopling (VRP), dan panjang ikatan sensitizer dengan $\mathrm{TiO}_{2}$. Penelitian ini diawali dengan optimasi molekul menggunakan metode DFT dan TDDFT dengan basis set $6.311 G^{*}$. Untuk parameter HOMO-LUMO digunakan metode yang sama dengan teknik analisis menggunakan ECCE. Parameter lokalisasi elektron LUMO menggunakan metode yang sama, namun teknik analisis menggunakan ECCE. Spektra menggunakan data dari metode DFT, menggunakan teknik analisis menggunakan software Chemcraft. Parameter efisiensi penyerapan cahaya menggunakan metode DFT dan TDDFT. Parameter konstanta kopling menggunakan metode yang sama, teknik perhitungan menggunakan persamaan energi senyawa dye pada kondisi HOMO, LUMO dan energi $\mathrm{TiO}_{2}$. Parameter panjang ikatan sensitizer dengan $\mathrm{TiO}_{2}$ menggunakan metode DFT dengan teknik analisis avogadro. Sianidin sianoasetat menjadi modifikasi terbaik berdasarkan parameter energi HOMO LUMO dengan hasil -4,569 dan -1,01 eV. Pada parameter lokalisasi elektron, modifikasi terbaik dihasilkan pada sianidin sianoasetat dengan pola elektron berpusat pada gugus sianoasetat. Parameter spektra menghasilkan modifikasi terbaik yaitu sianidin sianoasetat dengan panjang gelombang 378,811 nm dengan kekuatan osillator 0,633. Parameter efisiensi penyerapan cahaya menghasilkan modifikasi terbaik pada sianidin sianoasetat dengan nilai sebesar 0,767. Parameter konstanta kopling, modifikasi terbaik adalah sianidin benzothiadizol sianoakrilik dengan nilai -0,269. Modifikasi terbaik pada parameter panjang ikatan sensitizer dengan $\mathrm{TiO}_{2}$ adalah sianidin sianoasetat dengan panjang ikatan sebesar $1,926 \AA$.

\section{Introduction}

Penggunaan sianidin untuk senyawa dye pada DSSC juga telah dipelajari secara komputasi. Salah satunya penelitian yang dilakukan oleh Ainurraziqin [1] yaitu mengkombinasikan antara sianidin dengan salah satu asam siano, yakni sianoasetat. Metode komputasi yang digunakan adalah metode DFT dan TDDFT dengan basis set 6-31G*. Hasil yang diperoleh menunjukkan sianidin dengan modifikasi sianoasetat memiliki panjang ikatan sebesar 1,937 $\AA$ dengan selisih energi HOMO-LUMO sebesar 3,21 eV.

Galappaththi $d k k$. [2] mengkombinasikan sianidin dengan sianosinamat menggunakan metode DFT dan TDDFT. Hasil yang diperoleh menunjukkan energi LUMO sianosinamik yang dimodifikasi dengan sianidin memiliki nilai tertinggi dari pita konduksi tingkat $\mathrm{TiO}_{2}$. Sianidin memiliki tingkat LUMO tanpa optimasi sebesar $3.82 \mathrm{eV}$ dan tingkat LUMO dengan optimasi sebesar -3.39 eV. Sementara itu, untuk sianidin yang dimodifikasi dengan sianosinamik memiliki hasil energi LUMO sebesar $-3,90 \mathrm{eV}$ dan $-3.66 \mathrm{eV}$.
Turunan asam siano yang lain, dipelajari oleh $\mathrm{Wu}$ dan Zhu [3] menggunakan sianovinil yang diikat pada senyawa trifenilamin. Metode yang digunakan, yaitu DFT dengan tingkat B3LYP/6.31G*. Hasilnya menunjukkan tingkat LUMO senyawa sianovinil menjadi akseptor elektron, sehingga dapat digunakan sebagai DSSC tipe-p dan menghasilkan selisih energi HOMO-LUMO, yaitu $0.67 \mathrm{eV}$.

Turunan asam siano lainnya yang telah dipelajari adalah benzothiadizol sianoakrilik [4]. Parameter yang dipelajari adalah energi eksitasi dan kekuatan osillator dengan menggunakan metode TDDFT. Hasilnya menunjukkan penggunaan benzothiadizol sianoakrilik pada DSSC dilakukan dengan pengukuran pada tingkat HOMO-LUMO diperoleh selisih sebesar $2.57 \mathrm{eV}$, sedangkan nilai kekuatan osillator sebesar 1.3202.

Parameter lain yang dapat diukur secara komputasi yang dilakukan oleh Fan dkk. [5] yaitu efisiensi penyerapan cahaya atau light harvesting efficiency (LHE). Nilai LHE senyawa fenil 4- [bis(4-oktooksilfenil)] amino dengan senyawa dye APP-IV menggunakan metode DFT sebesar 0.8611 , nilai $\mathrm{V}_{\text {oc }} 691 \mathrm{mV}$, faktor pengisian sel (FF) sebesar 0.76 , dan efisiensi sebesar $7.12 \%$. 
Perhitungan nilai efisiensi penyerapan cahaya (LHE) dilakukan oleh Qin $d k k$. [6] untuk senyawa trifenilamin menggunakan metode DFT dan TDDFT. Hasilnya menunjukkan nilai LHE sebesar 0.9677. Dua penelitian di atas menunjukkan bahwa nilai LHE dapat digunakan sebagai parameter teoritis DSSC.

Parameter DSSC lain yang dapat diukur secara komputasi adalah konstanta kopling $\left(\mathrm{V}_{\mathrm{RP}}\right)$ [7]. Senyawa MnO dapat menentukan nilai konstanta kopling dengan menggunakan metode DFT. Hasil penelitian menunjukkan bahwa MnO memproduksi sedikit konstanta kopling magnetik dan struktur rhombohedral terdistorsi. Sifat $\mathrm{MnO}$ dihitung dengan generalizated gradient approximation (GGA-). Penelitian di atas menunjukkan nilai konstanta kopling dapat digunakan sebagai parameter teoritis DSSC.

Berdasarkan uraian di atas, potensi pemanfaatan sianidin sebagai senyawa dye pada DSSC diharapkan dapat dimaksimalkan menggunakan turunan asam siano. Penelitian ini dilakukan secara teoritis untuk memperkirakan sifat-sifat dan peningkatan efisiensi sianidin sebagai senyawa dye DSSC. Modifikasi yang dilakukan yaitu menggunakan sianidin sebagai donor dan turunan asam siano sebagai akseptor elektron. Perubahan basis set dapat menghasilkan hasil yang lebih akurat dan baik. Sehingga pada penelitian ini digunakan metode DFT dan TDDFT dengan basis set $6.311 \mathrm{G}^{*}$.

Parameter teoritis yang akan digunakan untuk mengetahui hasil modifikasi tersebut adalah energi HOMO-LUMO, lokalisasi elektron LUMO, spektra, efisiensi penyerapan cahaya (light harvesting efficiency), konstanta kopling $\left(\mathrm{V}_{\mathrm{RP}}\right)$, dan panjang ikatan sensitizer dengan $\mathrm{TiO}_{2}$. Perbedaan sebaran elektron pada masingmasing modifikasi akan menyebabkan perbedaan nilai pada masing-masing parameter tersebut.

\section{Metode Penelitian}

\subsection{Alat Penelitian}

Alat-alat yang digunakan dalam penelitian ini, meliputi perangkat hardware dan software. Perangkat hardware yang digunakan yaitu Personal Computer (PC) Intel Core i7-4770 3.40 GHz, dan RAM 8GB. Sedangkan, perangkat software yang digunakan meliputi NWCHEM, ECCE, Chemcraft, dan Avogadro yang dijalankan pada sistem operasi Linux Mint.

\subsection{Cara Kerja Penelitian}

Molekul sianidin dan sianidin termodifikasi turunan asam siano digambar dengan menggunakan Avogadro. Kemudian dilakukan optimasi molekul menggunakan metode DFT untuk keadaan dasar dan metode TDDFT untuk keadaan tereksitasi dengan basis set $6.311 \mathrm{G}^{*}$ menggunakan NWCHEM. Visualisasi molekul, energi, dan orbital molekul menggunakan ECCE. Untuk visualisasi spektra menggunakan Chemcraft. Langkah terakhir yaitu menggambar variasi molekul yang direaksikan dengan $\mathrm{TiO}_{2}$ guna mempelajari interaksinya.

\section{Hasil dan Pembahasan}

\subsection{Pemilihan Metode}

Selisih energi eksitasi eksperimen dengan energi eksitasi perhitungan pada tabel 1 sebesar $0,267 \mathrm{eV}$ dan persentase sebesar $89,385 \%$. Hasil ini menunjukkan bahwa penggunaan basis set $6.311 \mathrm{G}^{*}$ cukup akurat. Hal ini berdasarkan persentase perbandingan hasil perhitungan mendekati hasil eksperimen.

Tabel 1. Energi eksitasi sianidin eksperimen dan perhitungan

\begin{tabular}{lccc}
\hline No & Data & Energi Eksitasi $(\mathrm{eV})$ & Keterangan \\
\hline 1 & Eksperimen & 2,3175 & Harborne [8] \\
2 & Perhitungan & 2,5927 & Hasil perhitungan \\
\hline
\end{tabular}

3.2. Optimasi Molekul dan Energi HOMO LUMO

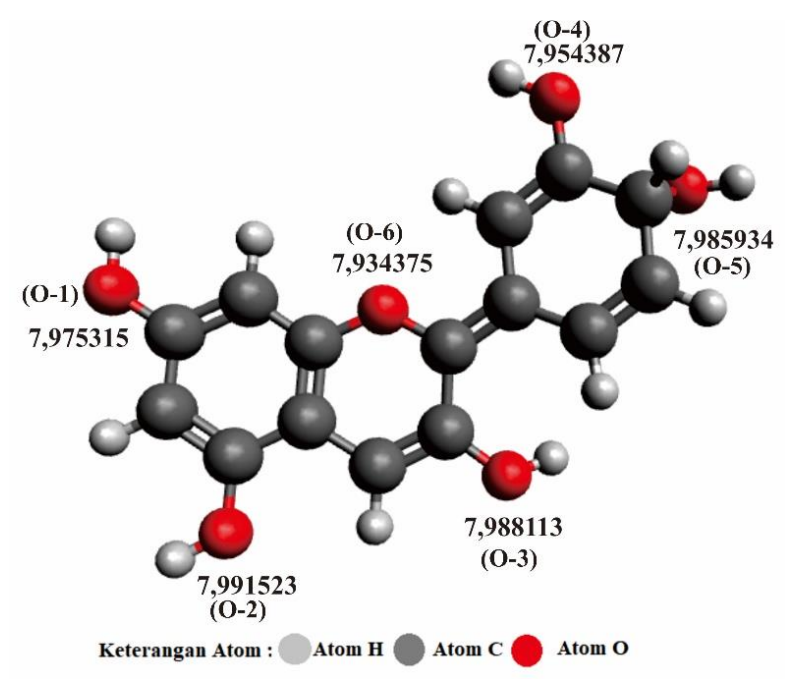

Gambar 1. Optimasi sianidin dengan metode DFT

Dari hasil optimasi didapatkan nilai mullken sianidin yang berbeda-beda. Atom O-2 dan O-3 memiliki urutan muatan mulliken yang lebih tinggi jika dibandingkan dengan atom 0-1, 0-4, 0-5, dan 0-6. Hal itu menunjukkan bahwa atom O-2 dan O-3 memiliki kecenderungan menarik elektron-elektron yang lebih besar dibandingkan dengan atom O lainnya. Pemilihan atom $\mathrm{O}-3$ untuk mengikat gugus sianoasetat, benzothiadizol sianoakrilik, sianovinil, sianosinamik berdasarkan pertimbangan sterik molekul. 


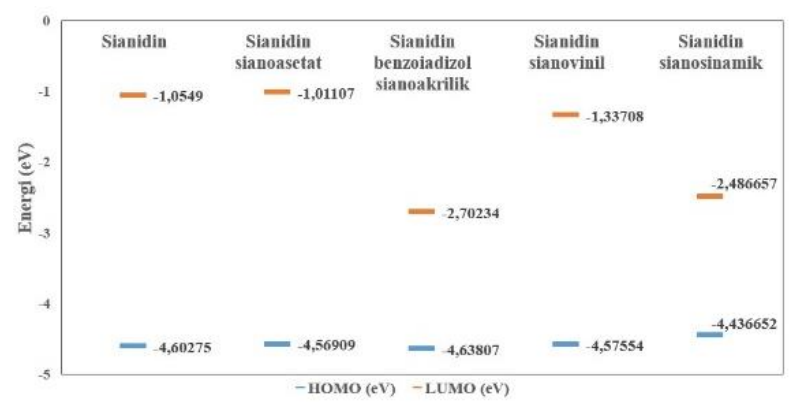

Gambar 2. Energi HOMO LUMO pada sianidin, sianidin sianoasetat, sianidin benzothiadizol sianoakrilik, sianidin sianovinil, dan sianidin sianosinamik

Berdasarkan gambar 2, energi HOMO LUMO terbaik adalah sianidin sianoasetat. Ini diakibatkan karena adanya gugus sianoasetat yang terdiri dari gugus siano dan gugus karboksilat. Gugus siano merupakan gugus fungsi penarik elektron. Sementara itu, selisih energi HOMO-LUMO sianidin sianoasetat, yaitu sebesar 3,558 eV yang merupakan selisih energi HOMO-LUMO terbesar di antara sianidin, sianidin benzothiadizol sianoakrilik, sianidin sianovinil, dan sianosinamik. Selisih energi HOMO-LUMO besar menyebabkan mengeksitasi satu elektron dari HOMO menuju LUMO sulit karena jarak antara HOMO dan LUMO jauh.

\subsection{Posisi Orbital Elektron pada Keadaan LUMO}

Keadaan LUMO sianidin disajikan pada gambar 3, dimana elektron sianidin lebih cenderung menyebar di tengah. Hal ini memberikan suatu pertimbangan untuk menentukan ikatan antara molekul sianidin dengan $\mathrm{TiO}_{2}$, sementara Ti pada $\mathrm{TiO}_{2}$ akan lebih efektif jika diikatkan dengan atom $\mathrm{O}-2$ sianidin.

Sianidin sianoasetat yang terdapat pada gambar 3, orbital energi keadaan LUMO, elektron mengalami pergeseran ke gugus sianoasetat secara merata. Berdasarkan hal tersebut, $\mathrm{TiO}_{2}$ akan lebih sesuai untuk dikaitkan dengan gugus karboksilat pada gugus sianoasetat sehingga transfer muatan dari sensitizer ke semikonduktor menjadi lebih efektif.

Orbital energi keadaan LUMO pada sianidin benzothiadizol sianoakrilik, elektron masih berada pada atom $0-3$ pada gugus sianidin. Oleh karena itu, sianidin benzothiadizol sianoakrilik akan berikatan dengan $\mathrm{TiO}_{2}$ pada atom $O$ gugus karboksilat, sehingga transfer muatan dari sensitizer ke semikonduktor menjadi lebih efektif.

Tipe sebaran elektron pada orbital energi LUMO sianidin sianovinil memiliki kesamaan tipe sebaran elektron pada sianidin benzothiadizol sianoakrilik. Keadaan LUMO elektron menyebar ke gugus sianovinil dan atom O-2 pada gugus sianidin. Oleh karena itu, sianidin sianovinil akan lebih sesuai untuk berikatan dengan $\mathrm{TiO}_{2}$ dengan atom $\mathrm{O}$ gugu karboksilat, sehingga transfer muatan dari sensitizer ke semikonduktor menjadi lebih efektif.
Berdasarkan parameter lokalisasi elektron LUMO, modifikasi terbaik adalah sianidin sianoasetat. Dikarenakan sebaran elektron ketika posisi LUMO berada pada gugus sianoasetat, sehingga ketika diikatkan pada semikonduktor $\mathrm{TiO}_{2}$ elektron akan mudah bergeser ke semikonduktor $\mathrm{TiO}_{2}$.

a.

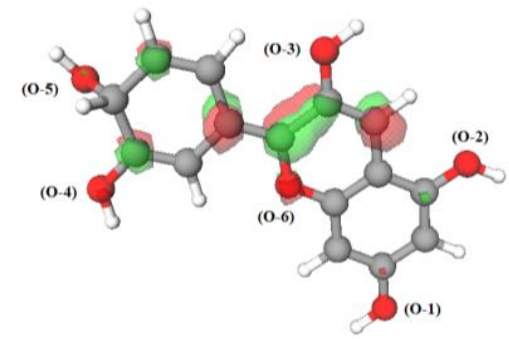

b.

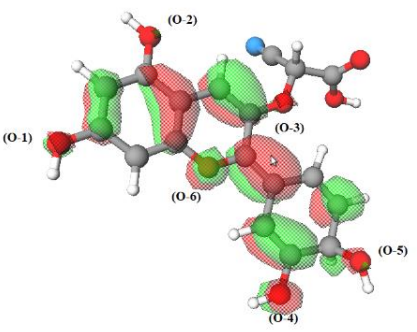

c.

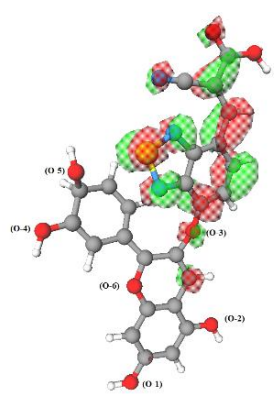

d.

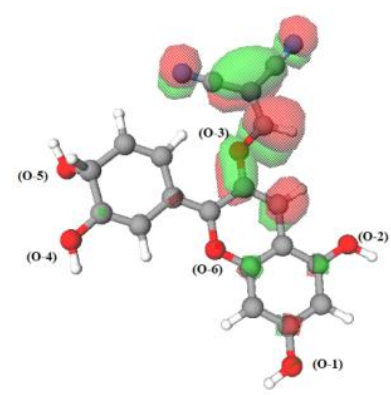

e.

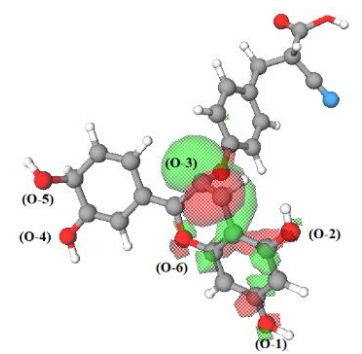

Keterangan Atom : Atom $\mathrm{H} \bigcirc$ Atom C

Atom 0

Atom N

Atom $S$

Gambar 3. Orbital (a) sianidin, (b) sianidin sianoasetat,(c) sianidin benzothiadizol sianoakrilik, (d) sianidin sianovinil, dan (e) sianidin sianosinamik pada posisi LUMO 


\subsection{Spektra}

Sianidin memiliki serapan maksimum pada panjang gelombang 478,204 nm dengan kekuatan osilator 0,480 pada daerah tampak. Sianidin sianoasetat memiliki serapan maksimum pada panjang gelombang $378,811 \mathrm{~nm}$ dengan kekuatan osilator 0,633 pada daerah tampak. Sianidin benzothiadizol sianoakrilik pada gambar 4 menunjukkan adanya serapan kuat pada panjang gelombang 419,838 nm dan osilator 0,475. Sianidin sianovinil memiliki panjang gelombang maksimum dan kekuatan osilator sebesar 237,823 $\mathrm{nm}$ dan 0,614. Selanjutnya, sianidin sianosinamik pada gambar 4 menunjukkan adanya serapan kuat pada panjang gelombang 424,647 $\mathrm{nm}$ dengan kekuatan osilator 0,489.

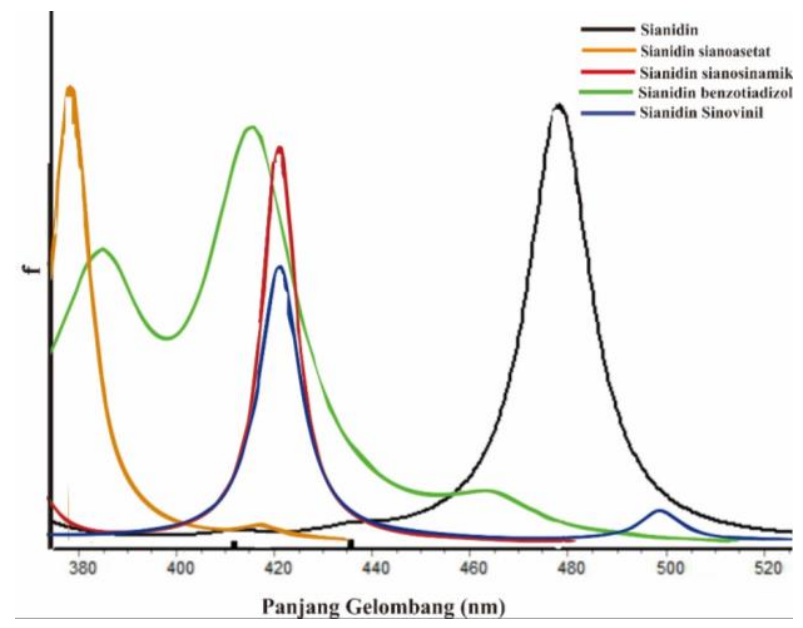

Gambar 4. Spektra absorpsi sianidin, sianidin sianoasetat, sianidin benzothiadizol sianoakrilik, sianidin sianovinil, dan sianidin sianosinamik

Berdasarkan parameter spektra, modifikasi terbaik adalah sianidin sianoasetat. Panjang gelombang sianidin sianoasetat berada lebih rendah dibandingkan dengan sianidin, sementara untuk nilai osilator mengalami kenaikan. Kemudian, adanya gugus sianoasetat menyebabkan pergeseran daerah serapan. Gugus sianoasetat tersusun dari gugus karboksilat dan gugus siano. Hasil ini bertolak belakang dengan pengukuran energi HOMO-LUMO dimana siano asetat memiliki Egap terbesar sehingga disebutkan sulit untuk eksitasi elektron dibandingkan dengan sianidin, sianidin benzothiadizol sianoakrilik, sianidin sianovinil, dan sianidin sianosinamik.

\subsection{Efisiensi Penyerapan Cahaya}

Efisiensi penyerapan cahaya menunjukkan fraksi intensitas cahaya yang diserap oleh senyawa dye pada DSSC. Sinar matahari memiliki variasi panjang gelombang yang banyak, 99\% di antaranya merupakan sinar tampak dan sisanya adalah sinar UV. Nilai efisiensi penyerapan cahaya sianidin ditampilkan pada tabel 2 sebesar 0,668 dengan panjang gelombang 478,203 nm. Sianidin sianoasetat memiliki nilai efisiensi penyerapan cahaya sebesar 0,767 dengan panjang gelombang 378,811 $\mathrm{nm}$ dikarenekan untuk sianidin benzothiadizol sianoakrilik menghasilkan nilai efisiensi penyerapan cahaya sebesar 0,665 dengan panjang gelombang 419,838 nm. Nilai efisiensi penyerapan cahaya untuk sianidin sianovinil yaitu 0,756 pada panjang gelombang 237,822 nm dan untuk sianidin sianosinamik menghasilkan efisiensi penyerapan cahaya sebesar 0,675 pada panjang gelombang 424,646 nm. Nilai efisiensi penyerapan cahaya terbaik adalah 0,767 pada sianidin sianoasetat. Pergeseran ke arah panjang gelombang yang lebih kecil dan kenaikan nilai efisiensi penyerapan cahaya terjadi karena adanya gugus sianoasetat.

Tabel 2. Efisiensi penyerapan cahaya pada sianidin, sianidin sianoasetat, sianidin benzothiadizol sianoakrilik, sianidin sianovinil, dan sianidin sianosinamik

\begin{tabular}{lcc}
\hline \multicolumn{1}{c}{ Senyawa } & $\begin{array}{c}\text { Panjang } \\
\text { Gelombang }(\mathrm{nm})\end{array}$ & LHE \\
\hline Sianidin & 478,204 & 0,66850 \\
Sianidin sianoasetat & 378,811 & 0,76723 \\
Sianidin benzothiadizol & 419,838 & 0,66517 \\
Sianoakrilik & & \\
Sianidin sianovinil & 237,823 & 0,75656 \\
Sianidin sianosinamik & 424,647 & 0,67570 \\
\hline
\end{tabular}

3.6. Konstanta Kopling

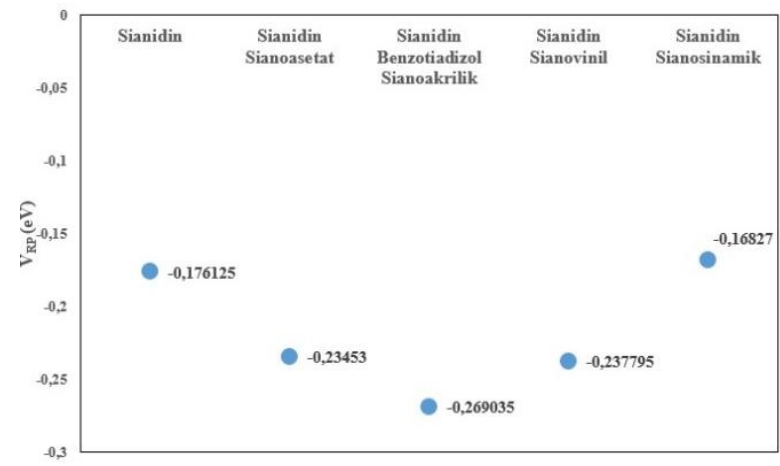

Gambar 5. Konstanta kopling sianidin, sianidin sianoasetat, sianidin benzothiadizol sianoakrilik, sianidin sianovinil, dan sianidin sianosinamik

Kopling terbentuk dari interaksi antar keadaan spin yang berbeda akibat ikatan kimia suatu molekul dan menyebabkan pemecahan sinyal. Konstanta kopling merupakan perbedaan frekuensi terhadap dua garis multiplet sederhana. Konstanta kopling juga merupakan bukti dari adanya interaksi antar inti yang berdekatan.

Sianidin, sianidin sianoasetat, sianidin benzothiadizol sianoakrilik, sianidin sianovinil, dan sianidin sianosinamik mempunyai nilai $V_{\mathrm{RP}}$ yang bervariasi. Sianidin sianosinamik memiliki nilai $V_{R P}$ sebesar -0,168 eV. Kemudian, sianidin dengan nilai $\mathrm{V}_{\mathrm{RP}}$ sebesar $-0,176 \mathrm{eV}$ dan berurutan sianidin sianoasetat, sianidin sianovinil, dan sianidin benzothiadizol sianoakrilik dengan nilai masing-masing -0,235 eV; $0,238 \mathrm{eV} ;-0,269 \mathrm{eV}$. 
Berdasarkan nilai konstanta kopling, modifikasi terbaik adalah sianidin dengan akseptor elektron benzothiadizol sianoakrilik. Sianidin benzothiadizol sianoakrilik mengalami perubahan yang cukup jauh dibandingkan dengan sianidin dikarenakan pada senyawa ini terdapat cincin aromatis, adanya ikatan antara N-S, serta terdapat gugus siano dan karboksilat. Cincin aromatis menyebabkan adanya efek dishelding terhadap lingkungan sehingga mengubah nilai $V_{\mathrm{RP}}$.

\subsection{Panjang Ikatan}

Panjang ikatan dihitung untuk mengetahui ada atau tidaknya ikatan antara masing-masing molekul dengan semikonduktor $\mathrm{TiO}_{2}$ anatase. Menurut Affandi [9], dua atom dikatakan berikatan apabila nilai panjang ikatan lebih kecil daripada penjumlahan jari-jari atom. Jari-jari atom $\mathrm{TiO}_{2}$ sebesar 2,36 ̊.

Tabel 3. Panjang ikatan sianidin, sianidin sianoasetat, sianidin benzothiadizol sianoakrilik, sianidin sianovinil, dan sianidin sianosinamik

\begin{tabular}{lccc}
\hline \multicolumn{1}{c}{ Senyawa } & Ikatan & $\begin{array}{c}\mathrm{Jari}-\text { jari } \\
\mathrm{TiO}_{2}(\AA)\end{array}$ & $\begin{array}{c}\text { Panjang } \\
\text { Ikatan }(\AA)\end{array}$ \\
\hline Sianidin & $\mathrm{Ti}-\mathrm{O}$ & 2,36 & 1,945 \\
Sianidin sianoasetat & $\mathrm{Ti}-\mathrm{O}$ & 2,36 & 1,926 \\
$\begin{array}{l}\text { Sianidin benzothiadizol } \\
\text { sianoakrilik }\end{array}$ & $\mathrm{Ti}-\mathrm{O}$ & 2,36 & 1,960 \\
Sianidin sianovinil & $\mathrm{Ti}-\mathrm{O}$ & 2,36 & 2,043 \\
Sianidin sianosinamik & $\mathrm{Ti}-\mathrm{O}$ & 2,36 & 1,943 \\
\hline
\end{tabular}

Dari tabel 3 menunjukkan bahwa panjang ikatan sianidin dengan sianidin sianoasetat selisih 0,019 ̊, hal ini mengindikasikan bahwa gugus sianoasetat memberikan pengaruh yang tidak terlalu signifikan terhadap panjang ikatan $\mathrm{TiO}_{2}$. Modifikasi sianidin sianoasetat merupakan modifikasi terbaik jika didasarkan pada panjang ikatan antara dye dan semikonduktor $\mathrm{TiO}_{2}$.

\section{Kesimpulan}

Sianidin sianoasetat merupakan hasil modifikasi terbaik pada lima dari enam parameter, parameter energi HOMO LUMO dengan hasil -4,569 dan -1,01 eV. Pada parameter lokalisasi elektron, modifikasi terbaik dihasilkan pada sianidin sianoasetat dengan pola elektron berpusat pada gugus sianoasetat. Parameter spektra menghasilkan modifikasi terbaik yaitu sianidin sianoasetat dengan panjang gelombang 378,811 nm dengan kekuatan osillator 0,633. Parameter efisiensi penyerapan cahaya menghasilkan modifikasi terbaik pada sianidin sianoasetat dengan nilai sebesar 0,767. Parameter konstanta kopling, modifikasi terbaik adalah sianidin benzothiadizol sianoakrilik dengan nilai -0,269. Modifikasi terbaik pada parameter panjang ikatan sensitizer dengan $\mathrm{TiO}_{2}$ adalah sianidin sianoasetat dengan panjang ikatan sebesar 1,926 ̊

\section{Ucapan Terimakasih}

Para penulis berterima kasih kepada Bapak Sudarlin untuk diskusi yang terkait dengan pekerjaan ini. Jurusan kimia untuk penyedia fasilitas. Laboratorium komputer untuk fasilitas komputer.

\section{Daftar Pustaka}

[1] Moh. Irfan Ainurraziqin, Kajian Teoritis Pengaruh Gugus Trifenilamin dan Sianoasetat pada Sianidin sebagai Senayawa Dye Sel Surya Tersensitasi (DSS), Department of Chemistry, UIN Sunan Kalijaga, Yogyakarta

[2] Kalpana Galappaththi, Piyasiri Ekanayake, Mohammad Iskandar Petra, Computational study of modification of cyanidin as high efficient organic sensitizer for dye sensitized solar cells, Scientia Bruneiana, 15, Special issue, (2016)

[3] Yongzhen $\mathrm{Wu}$, Weihong $\mathrm{Zhu}$, Organic sensitizers from $D-\pi-A$ to $D-A-\pi-A$ : effect of the internal electron-withdrawing units on molecular absorption, energy levels and photovoltaic performances, Chemical Society Reviews, 42, 5, (2013) 2039-2058 http://doi.org/10.1039/C2CS35346F

[4] I. N. Obotowo, I. B. Obot, U. J. Ekpe, Organic sensitizers for dye-sensitized solar cell (DSSC): Properties from computation, progress and future perspectives, Journal of Molecular Structure, 1122, (2016) 80-87 https://doi.org/10.1016/j.molstruc.2016.05.080

[5] Wenjie Fan, Dazhi Tan, Wei-Qiao Deng, AceneModified Triphenylamine Dyes for Dye-Sensitized Solar Cells: A Computational Study, ChemPhysChem, 13, 8, (2012) 2051-2060 http://doi.org/10.1002/cphc.201200064

[6] Peng Qin, Hongjun Zhu, Tomas Edvinsson, Gerrit Boschloo, Anders Hagfeldt, Licheng Sun, Design of an Organic Chromophore for P-Type Dye-Sensitized Solar Cells, Journal of the American Chemical Society, 130, 27, (2008) 8570-8571 http://doi.org/10.1021/ja8001474

[7] Andrew J. Logsdail, Christopher A. Downing, C. Richard A. Catlow, Alexey A. Sokol, Magnetic coupling constants for $\mathrm{MnO}$ as calculated using hybrid density functional theory, Chemical Physics Letters, 690, (2017) https://doi.org/10.1016/j.cplett.2017.10.027

47-53

[8] J. B. Harborne, Spectral methods of characterizing anthocyanins, The Biochemical journal, 70, 1, (1958) 22-28

[9] Affandi, Kajian Teoritis Pengaruh Gugus Trifenilamin dan Asam Sianoasetat pada Pelargonidin sebagai Senyawa Dye Sel Surya Tersensitasi (DSSC), Department of Chemistry, UIN Sunan Kalijaga, Yogyakarta 